\title{
特発性前骨間神経麻痺・後骨間神経麻痺の手術成績
}

\author{
信 藤 真 理* 副 島 修* 古賀 敬* 内 藤 正 俊*
}

\section{Clinical Results of Nontraumatic Anterior Interosscous Nerve Paralysis and Posterior Interosseous Nerve Paralysis}

\begin{abstract}
Shinri Nobuto*, Osamu Soejima*, Kei Koga*, and Masatoshi Naito*
当科における過去 7 年間の特発性前骨間神経麻痺および後骨間神経麻痺 7 症例の手術成績を報告する. 症例は前骨間神経麻痺 5 例, 後骨間神経麻痺 2 例であり, 6 力月以上保存的に加療するも MMT の改善が 2 以下の症例に対して神経剥離術を施行した。術後平均観察期間は 6.3 カ月であり, MMTにて 4 以上の 改善を認めた症例は前骨間神経麻痺で 2 例，後骨間神経麻㽻で 2 例であり，改善を認めなかった症例は 3 例であった．当院の成績では，前骨間神経麻痺では FDP 麻痺型が術後良好例が多かった。一方，後骨間 神経麻痺では全例母指，手指型であったが，術後全例で改善を認めた。 また術後 2 週間で徒手筋力の改善 を見せた症例が 7 例中 4 例で，すべて経過良好であった．術後急速に回復する症例の存在や，保存療法で 回復が遅い症例は予後が悪いとする報告もあり，6 カ月程度保存的に見て回復傾向が見られなければ，神 経剥離術を考慮する方が望ましいと考えられた。
\end{abstract}

Five patients with nontraumatic paralysis of the anterior interosseous nerve (AINP) and two patients with nontraumatic paralysis of the posterior interosseous nerve (PINP) treated conservatively for more than six months and showing less than manual muscle test (MMT) 2 were treated by interfascicular neurolysis.

Multiple constriction was seen in one case, and other cases showed edema or ischemic changes.

Four of the seven surgical cases (2 AINP, 2 PINP) recovered with MMT increased to more than [4] (good cases) from less than [2] at 12 months (average : 6.3 months) after surgery. Good cases showed muscle recovery with MMT more than [3] within two weeks. AINP with only FDP type and PINP with thumb and finger type showed useful recovery. From the results of these investigations, conservative treatment should be done at least six months after the onset of AINP or PINP and interfascicular neurolysis should be selected for cases of no tendency toward improvement within six months.

Key words : anterior interosseous nerve palsy（前骨間神経麻痺）, posterior interosseous nerve palsy (後骨間神経麻痺), clinical result（治療成績）

\section{は じめに}

特発性前骨間神経麻痺, 後骨間神経麻痺は比較的稀 な疾患であり，いまだ病態がはっきりせず，診断や治 療に苦慮することがある，治療方法としては，長期間 の保存療法を勧める報告がある一方で, 神経剥離術が 有効であるとする報告も散見される，今回我々が経験 した特発性前骨間神経麻痺, 後骨間神経麻痺について
臨床像, 手術所見, 治療成績について検討したので若 干の文献的考察を加えて報告する.

$$
\text { 対象 }
$$

1997 年から 2004 年の 8 年間で, 6 カ月以上保存的 に加療するも, 徒手筋力テスト (以下 MMT) が 2 以 下の 7 症例（非外傷性前骨間神経麻痺 5 例，後骨間神 経麻痺 2 例）を対象とした.

\footnotetext{
* 福岡大学病院整形外科 Department of Orthopadic Surgery, School of Medicine, Fukuoka University, Fukuoka, Japan
} 
前骨間神経麻痺症例 5 例，男性 3 例，女性 2 例，平 均年齢 40.2 歳（24～57 歳）であり，保存治療期間は 平均 7 力月で, 術後経過観察期間は平均 6.4 力月であつ た.

後骨間神経麻痺症例 2 例, 男性 1 例, 女性 1 例, 平 均年齢 41 歳であり, 保存治療期間は平均 6 力月で, 術後経過観察期間は平均 7.5 カ月であつた。治療成績 は MMT にて 4 以上に回復した例を良好として評価 した.

$$
\text { 結果 }
$$

前骨間神経麻痺の麻痺形態は，櫛田らにならい tear drop shaped deformity を呈する完全型と, 示 指深指屈筋 (FDP) 単独麻痺, 長母指屈筋 (FPL) 単独麻痺の不全型に分類 ${ }^{1)}$ した. 完全型を 3 例に, FDP 単独麻痺例を 2 例に認めた。

後骨間神経麻痺の麻痺形態は, 平山らにならい, 母 指 - 手指伸展不能型, 手指伸展不能型, 母指伸展不能 型に分類 ${ }^{2)}$ した. 母指 - 手指伸展不能型 2 例, 母指伸 展不能型および手指伸展不能型は認めなかつた.

全ての症例に神経剥離術を施行した。前骨間神経麻 痺では，圧痛部を中心に円回内筋近位縁に沿って皮切 を加え内上顆近位約 $10 \mathrm{~cm}$ まで展開した，後骨間神経
麻痺は圧痛部を中心に腕橈骨筋尺側縁に沿つて皮切を 加え外上顆まで展開した。

前骨間神経麻痺の症例は全て前腕部から肘部の疼痛 で発症した。術中所見では全ての症例で明らかな神経 の絞扼を認めず，青色調変化と浮腫状所見を認めた症 例が 4 例，くびれを認めた症例が 1 例であった. 5 例 中 3 例が徒手筋力 5 まで回復した。他の 2 例は明らか な改善を認めなかつた（表 1$)$.

後骨間神経麻痺の 2 症例とも前骨間神経麻痺症例之 同様に前腕側の疼痛より発症した。術中に明らかな絞 扼所見はなく，青色調変化と浮腫状所見を認めた． 2 例とも MMT が $4^{+}$から 5 まで回復した（表 2).

$$
\text { 症例 }
$$

症例 $1: 57$ 歳, 男性. 誘因なく右前腕部の疼痛が出 現し，翌日より右母指 IP 関節，示指 DIP 関節の屈曲 制限が出現した。初診時の MMTは 0 で Tear drop shaped deformity を認めた（図 1 a)。前骨間神経麻 痺と診断し保存加療を行うも MMT の改善を認めず, 神経剥離術を施行した。手術所見では神経の絞扼所見 はなかったが，青色調変化および浮腫状変化を呈して いた（図 1 b). 術後 5 カ月経過時点では MMT1 であつ た.

表 1 症例 (AINP)

\begin{tabular}{c|c|c|c|c|c|c|c}
\hline \hline 年齢 & 性 & 発症形式 & $\begin{array}{c}\text { 麻痺型 } \\
(\mathrm{MMT})\end{array}$ & 保存期間 & 手術所見 & 観察期間 & $\begin{array}{c}\text { 結果 } \\
(\mathrm{MMT})\end{array}$ \\
\hline 50 & 女 & 疼痛 & $\begin{array}{c}\text { 典型例 } \\
(1 \sim 2)\end{array}$ & $6 \mathrm{Mo}$ & $\begin{array}{c}\text { 絞扼なし } \\
\text { 青色調, 浮腫状 }\end{array}$ & $5 \mathrm{Mo}$ & $\begin{array}{c}\text { 不良 } \\
(2)\end{array}$ \\
\hline 25 & 男 & $\begin{array}{c}\text { 前腕部 } \\
\text { の疼痛 }\end{array}$ & $\begin{array}{c}\text { FDP 型 } \\
(0)\end{array}$ & $8 \mathrm{Mo}$ & $\begin{array}{c}\text { 絞扼なし } \\
\text { <びれあり }\end{array}$ & $8 \mathrm{Mo}$ & $\begin{array}{c}\text { 良好 } \\
(5)\end{array}$ \\
\hline 57 & 女 & $\begin{array}{c}\text { 前腕部 } \\
\text { の疼痛 }\end{array}$ & $\begin{array}{c}\text { 典型例 } \\
(1)\end{array}$ & $6 \mathrm{Mo}$ & $\begin{array}{c}\text { 男絞扼なし } \\
\text { 青色調, 浮腫状 }\end{array}$ & $9 \mathrm{Mo}$ & $\begin{array}{c}\text { 不良 } \\
(1)\end{array}$ \\
\hline 45 & $\begin{array}{c}\text { 典型例 } \\
(0)\end{array}$ & $8 \mathrm{Mo}$ & $\begin{array}{c}\text { 絞扼なし } \\
\text { 青色調, 浮腫状 }\end{array}$ & $5 \mathrm{Mo}$ & $\begin{array}{c}\text { 不良 } \\
(1 \sim 2)\end{array}$ \\
\hline 女 & $\begin{array}{c}\text { 前腕部 } \\
\text { の疼痛 }\end{array}$ & $\begin{array}{c}\text { FDP 型 } \\
(1)\end{array}$ & $6 \mathrm{Mo}$ & $\begin{array}{c}\text { 絞扼なし } \\
\text { 青色調, 浮腫状 }\end{array}$ & $5 \mathrm{Mo}$ & $\begin{array}{c}\text { 良好 } \\
(5)\end{array}$ \\
\hline
\end{tabular}

表 2 症例 (PINP)

\begin{tabular}{c|c|c|c|c|c|c|c}
\hline \hline 年齢 & 性 & 発症形式 & $\begin{array}{c}\text { 麻痺型 } \\
(\mathrm{MMT})\end{array}$ & 保存期間 & 手術所見 & 観察期間 & $\begin{array}{c}\text { 結果 } \\
(\mathrm{MMT})\end{array}$ \\
\hline 52 & 女 & 疼痛 & $\begin{array}{c}\text { 母指・手指型 } \\
(2)\end{array}$ & $6 \mathrm{Mo}$ & $\begin{array}{c}\text { 絞扼なし } \\
\text { 青色調, 浮腫状 }\end{array}$ & $12 \mathrm{Mo}$ & $\begin{array}{c}\text { 良好 } \\
(4 \sim 5)\end{array}$ \\
\hline 30 & 男 & 疼痛 & $\begin{array}{c}\text { 母指・手指型 } \\
(1 \sim 2)\end{array}$ & $6 \mathrm{Mo}$ & $\begin{array}{c}\text { 絞扼なし } \\
\text { 青色調, 浮腫状 }\end{array}$ & $3 \mathrm{Mo}$ & $\begin{array}{c}\text { 良好 } \\
(4+)\end{array}$ \\
\hline
\end{tabular}


症例 $2: 25$ 歳, 男性. 誘因なく右前腕部の疼痛が出 現し，翌日より示指 DIP 屈曲不能となつた。 5 年前 に左前骨間神経麻痺に対して神経剥離術を行い回復し た既往がある. 8 カ月保存治療したが改善を認めず, 神経剥離術を施行した。前骨間神経の明らかな絞扼所 見は認めなかつたが, 神経内の一本の神経束に砂時計 様変化を認めた（図 2). 術後 5 カ月経過で MMT5 ま で改善した。
症例 $3: 30$ 歳, 男性. 誘因なく左前腕部の疼痛が出 現，1 週間後より母指，手指伸展不能となつた（図 3 a). 6 力月の保存的治療をするも改善を認めず神経剥 離術を施行した。術中所見では後骨間神経に神経の明 らかな絞扼所見は認めなかつたが青色調変化および浮 腫状変化を認め, 神経変性をきたしていると思われた (図 3 b). 術後 2 週間で MMT4 まで改善, 術後 5 力 月で MMT5 まで改善した.

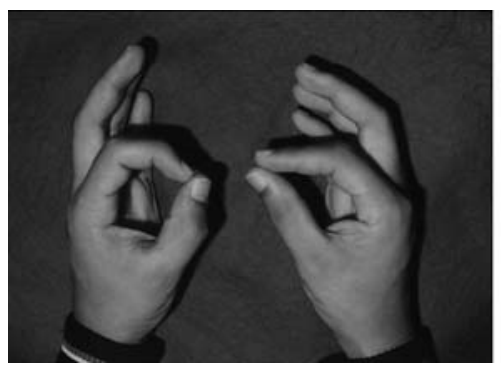

a

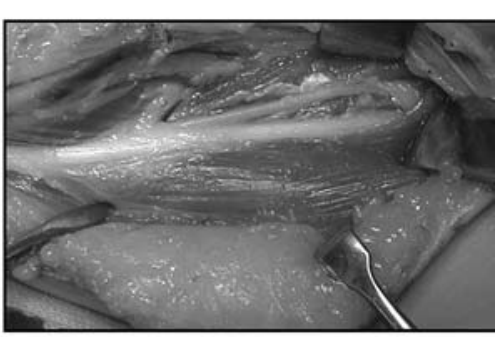

$\mathrm{b}$

図 157 歳, 男性, 右前骨間神経麻痺 a : 初診時. Tear drop shaped deformity を認めた $\mathrm{b}$ : 術中所見. 明らかな絞扼所見を認めず，青色調変化を認めた

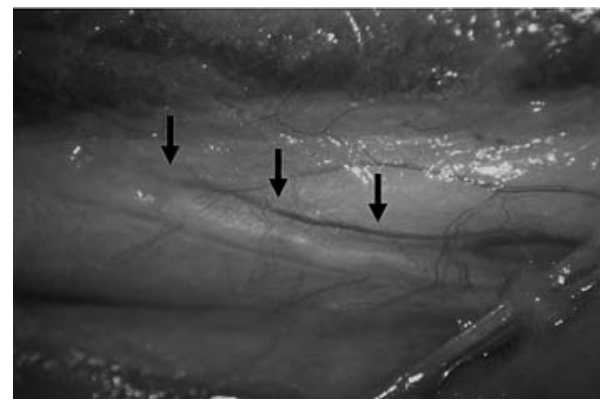

図 225 歳, 男性. 右前骨間神経麻痺 1 本の神経束に砂時計様くびれを認めた

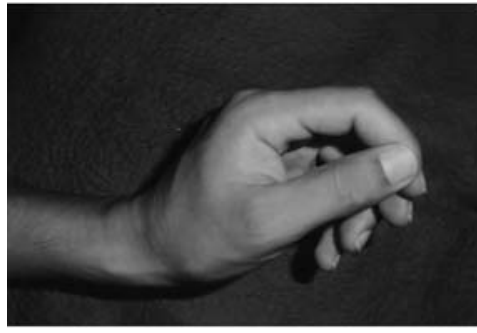

a

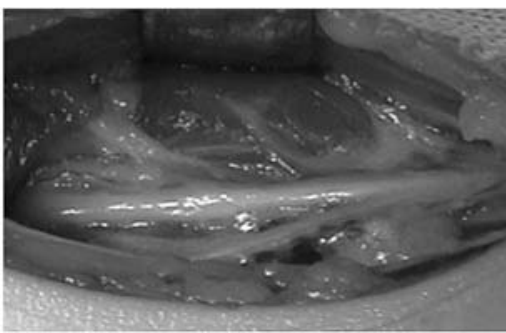

b

図 330 歳, 男性. 左後骨間神経麻痺 $\mathrm{a}$ : 初診時. 母指, 手指伸展不能

$\mathrm{b}$ : 術中所見. 後骨間神経は神経の青色調変化および浮腫状変化を認めた 


\section{考察}

特発性前・後骨間神経麻痺の診断, 治療法について は日常診療において苦慮することが多い. 原因として は腫瘍などの占拠病変 ${ }^{7)}$, 絞扼障害 ${ }^{7)}$, 神経炎 ${ }^{46)}$, Neuralgic Amyotrophy ${ }^{1)}$ などが上げられる. 治療方法 は保存療法, 神経剥離術, 神経切除・縫合術, 腱移行 術などがあるが，その選択や手術の時期，手術方法に 関して悩むところである.

二見らは Parsonage や Turner らの提唱する Neuralgic Amyotrophy を発展させ，その亜型である Forearm finger type を提唱している. (1)肘周囲の 疼痛後, 麻痺症状が出現. (2)時々, 前骨間神経, 後骨 間神経支配領域で筋力低下を認める. (3)ほとんどの症 例は 10 カ月以内に回復する ${ }^{1)}$. 等をあげている.

最近，日本を中心としたアジア地区でくびれに関す る文献が散見される．安永ら，Pan Yongweyらは全 例にくびれを認めたと述べており ${ }^{8)}$ ，浅見らはくびれ の形態からみた分類を提唱している. 今回我々の症例 では明らかな術中所見の絞扼所見はなく，1例にくび れを認めたのみであった。共に神経炎の可能性が考え られた。

Lundoborg は病因の仮説として神経内のコンパー トメント症候群の可能性をあげている ${ }^{1)}$. 上記につい て少し記述解説する. 神経周膜は, 外的からの防御の ために強いバリアーとなっており, 神経内でいったん 浮腫が起こると簡単には引かずに長時間持続してコン パートメント症候群を引き起こすのではないかと仮説 している.

櫛田らは前骨間神経麻痺では完全麻痺型が, 後骨間 神経麻痺では手指型が早期に回復するとの報告をして いる ${ }^{5)}$ ，我々の症例では，前骨間神経麻痺では FDP 型麻痺が術後早期に回復を認めた。一方後骨間神経麻 痺では，全例母指・手指伸展不能型であったが術後良 好例に回復した。

前骨間神経麻痺において完全麻痺例より FDP 単独 例で術後回復が良好であった理由として (1)神経障害の 範囲がより選択的で軽度の可能性, (2)FDPへの正中
神経本幹からの筋枝の存在が考えられた.

今回の検討では術後 2 週間で MMT の改善傾向を 認める症例が 7 例中 4 例で, すべて経過良好であった. 保存的に経過を見て回復時期が遅い症例は予後が悪い との報告例もあり ${ }^{2)} ， 6$ 力月程度保存的に経過を見て 改善傾向が認められない症例は神経剥離術を施行する のが望ましいと考えられた.

$$
\text { ま と め }
$$

(1)特発性前骨間神経麻痺 5 例，後骨間神経麻㽻 2 例 について術後成績を検討した.

(2)前骨間神経麻痺の典型例では術後成績が一定しな かったが，FDP 単独麻痺例では良好であった。

(3)後骨間神経麻痺例の術後成績は良好だった.

(4)半年程度の保存療法にて改善しない症例に対して は，神経剥離術を考慮する方が望ましい．

\section{参 考 文 献}

1）二見俊郎：前骨間神経麻痺を主徵とする疾患の検討. 整形外科, $34: 155-158,1983$.

2) Goran, L.: Commentary: Hourglass Like Facicular Nerve Compressions. J. Hand Surg., 28 : 212-213, 2003.

3）平山隆三他：後骨間神経麻痺の臨床像に関する検討. 日手会誌, $11 ： 385-387,1994$

4) Kiloh, L. G., et al.: Isolated neuritis of the anterior interosseous nerve. British Medical J., 19 : 850851, 1952.

5）櫛田 学他：非外傷性前骨間筋麻痺，後骨間筋麻痺の 治療経験。日手会誌, $16: 518-521,1999$.

6）前田敬三他：前骨間筋麻痺．整形外科，30：1255-1263, 1987.

7）長野 昭：前骨間筋麻痺。日手会誌，3：894-897, 1987.

8）田崎憲一他：神経束「くびれ」による前骨間神経麻痺 および後骨間神経麻㽻. 日手会誌, $13: 788-792,1996$.

9）山本真一他：前骨間神経麻痺の予後 神経線維束間剥 離例と保存療法の比較. 日手会誌, $15 ： 433-436,1998$.

10) Yongwei, P., et al.: Nontraumatic Paralysis of the Radial Nerve With Multiple Constrictions. J. Hand Surg., $28:$ 199-205, 2003. 